\title{
Ruslands undergang. Revolutioner og sammenbrud 1917-1921
}

\author{
Bent Jensen \\ Gyldendal: Köpenhamn 2017 \\ 526 sidor. ISBN 9788702244908
}

Recenserad av Klas-Göran Karlsson [Professor i historia, Lunds universitet, klas-goran.karlsson@hist.lu.se]

Varje historieskrivare som tar sig an den ryska revolutionen har ett antal grundläggande frågor att ta ställning till. En av dem rör revolutionsberättelsens början och slut, en annan huruvida revolutionens bakgrund skall framställas som rysk eller internationell, en tredje om revolutionens drivkrafter bör tecknas strukturellt, i termer av världskrig och samhällets sammanbrott, eller med fokus på centrala aktörer. En fjärde fråga rör revolutionens huvudaspekter: var det maktpolitiken som var revolutionens kärna, var det den tilltagande sociala konfliktutvecklingen, eller var det rentav den nationella eller nationalistiska aspekt som världskriget bar med sig som var avgörande?

Alla dessa i varandra inflätade frågor knyter därtill an till ett ännu större spörsmål, som handlar om vilken av de redan färdiga grand narratives om den ryska revolutionen som har utkristalliserat sig i historieskrivningen som man skall bekänna sig till. Skall man som historieskrivare hålla fast vid den vänsterorienterade och i grunden revolutionspositiva historia som ser 1917 års händelser i Petrograd som progressiva utvecklingar från en tsarledd, repressiv och underutvecklad autokrati till en löftesrik rörelse underifrån mot en modernare stat med större delaktighet och ekonomisk och social jämlikhet på programmet? Eller skall man snarare ta fasta på den mer högerorienterade och i grunden revolutionsnegativa historia som ser 1917 som en katastrof och en tragedi, när en grupp extremister drar nytta av oron och turbulensen i Ryssland till att ta makten för att med terror och diktatur förverkliga de utopiska ideologiska visioner som snart blev till dystopisk verklighet? De två grundberättelserna, Sheila Fitzpatricks "goda» mot Richard Pipes "onda", kompliceras förvisso av att det under 1917 ägde rum två maktskiften i Petrograd, ett i mars och ett i november, men $\mathrm{i}$ ingen av de två stora berättelserna brukar den första, "februarirevolutionen", då tsaren abdikerade och den provisoriska regeringen i konkurrens med 
sovjeterna tog makten, tillmätas annat än förstrött intresse. Det är Lenin och hans bolsjevikiska parti som stjäl uppmärksamheten.

Bent Jensens historia om den ryska revolutionsepoken, som involverar februarirevolutionen men även det efterföljande ryska inbördeskriget mellan "röda» och "vita", tillhör utan minsta tvekan den revolutionsnegativa typen. Man kanske till och med kan påstå att Jensen, med tidigare böcker om Stalinismens fascination og danske ventreintellektuelle (1984) och Gulag och glemsel. Ruslands tragedie og Vestens hukommelsestab $i$ det 20. århundrede (2002) har bidragit till att utveckla denna berättelse. Som i dessa verk utmärks hans nya historia av realhistorisk konkretion och kronologisk reda. Problemorienteringar och teoretiska spörsmål lyser med sin frånvaro. Jensens svar på frågorna ovan är tydliga och raka. Han börjar sin analys av revolutionens rötter i det "gamla» Ryssland med dess "annorlundahet", vilket indikerar att den ryska revolutionen för honom i hög grad är en rysk historia.

Ändå finns det också en europeisk komponent, främst iakttagbar i rubriken "Tysken Marx ryska elev, Lenin», och i revolutionens anknytning till första världskriget och dess förödande konsekvenser för det ryska samhället. Strukturella aspekter saknas alltså inte, men det är ändå aktörerna i allmänhet, och Lenin i synnerhet, som spelar huvudrollen hos Jensen. Den dubbelsidiga karaktärsteckningen av revolutionsledaren lämnar inte läsaren i något tvivel om att berättelsen är »ond». Lenin var förvisso politiskt flexibel, men samtidigt präglad av en absolutistisk ideologi: "Men han var så brændende sikker på, at han havde ret i sin marxistisk begrundede utopi om verdens og den lidende menneskeheds frelse, og han var samtidig så hensynsløs i sin kamp mod dem, han anså for mørkets kræfter, at han var blind og døv for de lidelser, han og hans regime påførte millioner af mennesker i det tidligere russiske imperium»(s.113). Att Lenin hade en alldeles avgörande betydelse för revolutionen och Rysslands framtid framgår av en fin passage där han jämförs med den provisoriska regeringens ledare Aleksandr Kerenskij. Denne skulle möjligen ha kunnat stoppa bolsjevikens framfart, men ändå inte, eftersom han anses sakna den hänsynslöshet och absoluta vilja som drev Lenin: "Hvis Kerenskij skulle have handlet anderledes, ville han ikke have været Kerenskij»(s. 148).

Jensens revolutionsberättelse inkluderar även vad han kallar »Leninryssland», det efterrevolutionära ryska samhälle som snabbt växte fram som en revolutionär diktatur, präglat av inbördeskrig, kamp för revolutionens överlevnad och upptrappad terror mot alla som betraktades som revolutionens fiender. Han tecknar också förtjänstfullt konturerna av ett krig på den kulturella fronten, där bolsjevikernas nyttobetonade kulturbegrepp stod mot utbildningskommissarien Anatolij Lunatjarskijs mer visionära föreställningar om en ny proletär kultur. Skillnaderna i kultursyn framträder klart, men det gör också, i Jensens uttolkning, deras gemensamma brist på kultur, moral och sanning, eller snarare deras uppfattning om maktens och ideologins absoluta primat.

Jensen vore till sist inte Jensen utan ett avsnitt om de danska hållningarna till revolutionshändelserna i Petrograd. En framträdande roll spelade karriärdiplomaten 
och sedermera utrikesministern Harald Scavenius, två gånger stationerad i den ryska huvudstaden och en kunnig och engagerad iakttagare. Under loppet av terroråret 1918 ville han att västliga regeringar skulle inträda i Ryssland med egnas trupper, förklara bolsjevikledarna fredlösa och efter kriget ställa dem inför rätta för deras illdåd. Man får intryck av att Scavenius skulle ha lätt att komma överens med sin historieskrivare.

Man behöver inte nödvändigtvis hålla med Jensen i alla hans tolkningar, och emellanåt känner åtminstone denne recensent ett behov av att stanna upp i läsningen och fundera $\mathrm{i}$ alternativa banor på de forskningsfrågor och vetenskapliga problem som han ställer oss inför, oftast utan att själv tala om det. En sak är dock klar: man har som läsare aldrig någonsin tråkigt i Jensens sällskap. 